\title{
The Effect of Gender, Ethnicity, and Income on College Students' Use of Communication Technologies
}

\author{
Reynol Junco, D.Ed., ${ }^{1}$ Dan Merson, M.A., ${ }^{2}$ and Daniel W. Salter, Ph.D. ${ }^{3}$
}

\begin{abstract}
Because campus officials are relying on personal communication technologies to communicate with students, a question arises about access and usage. Although communication technologies are popular among college students, some evidence suggests that differences exist in ownership and use. We examined patterns of student ownership and use of cell phones and use of instant messaging, focusing on three predictors of digital inequality: gender, ethnicity, and income. Logistic and hierarchical linear regression analyses were used to analyze results from 4,491 students. The odds that female and white students owned cell phones were more than twice as high as for men and African-American students. Students in the $\$ 100,000-\$ 149,000$ per year income bracket were more than three times as likely to own a cell phone than those from the median bracket. However, being female, AfricanAmerican, and/or from the highest income brackets was positively predictive of the number of text messages sent and the amount of time spent talking on a cell phone per week. We found no differences between students on the use of instant messaging. Implications of these results, as well as areas for further research, are provided.
\end{abstract}

\section{Introduction}

$\mathbf{R}$ ECENT EMERGENCIES AND TRAGIC EVENTS on college campuses have highlighted the need for effective and immediate communication with students and staff. ${ }^{1-3}$ Increasingly, school officials are using electronic communication strategies (e.g., campus-wide texting, computer-generated voice mail) to assure that accurate information is dispersed quickly. Importantly, even though student use of technology has rapidly increased, campus officials should remain mindful that students are not a homogenous group of users. In this study, we examined patterns of student use of communication technology, focusing specifically on three of the commonly recognized predictors of digital inequality: gender, ethnicity, and income. ${ }^{4-6}$

\section{Communication technologies on campus}

Communication technologies come in a variety of forms and are quickly becoming ubiquitous among college students. Appreciably, almost all students own or have access to computers on campus. ${ }^{7-9}$ The vast majority of students also own a cell phone, many of whom have no landline number., ${ }^{70}$ Other hardware items, such as digital music players, are increasingly prevalent. Phone and computer technologies are now merging with video, as seen in the increased use of technologies such as Skype, which reports over 300 million users worldwide (http://www.skype.com). Most recently, the "smart phone" (e.g., iPhone, Blackberry, or Palm) has emerged as a single device to replace all the others, and is poised to change the communication landscape yet again. ${ }^{11}$

These new hardware items allow students to communicate in new and novel ways, and to be connected to the Internet more than the general population. ${ }^{12}$ College students consult Wikipedia, ${ }^{13}$ play online games, own blogs, and download music more than individuals from earlier generations. $7,14,15$ Their styles of communication may be evolving as well. ${ }^{16}$ Instead of e-mail, which is less immediate and personal, many students now prefer to communicate with their peers through instant messaging (IM), text messaging, and/or socialnetworking sites (e.g., Facebook, MySpace), all of which are becoming integrated into sites like Twitter (which allows texting-based micro-blogging or "tweets"). ${ }^{7,16}$ Websites like YouTube and Flickr have pushed these boundaries even further by offering an easy method to incorporate user-generated photos and video. A new shorthand language has emerged (e.g., BRB, LOL, OMG), and all of these patterns are becoming increasingly integrated into students' digital lifestyles. ${ }^{7,16}$

Many campus officials and educators have been quick to embrace the opportunities presented by these technologies,

\footnotetext{
${ }^{1}$ Department of Academic Development and Counseling, Lock Haven University, Lock Haven, Pennsylvania.

${ }^{2}$ Department of Education Policy Studies, Pennsylvania State University, University Park, Pennsylvania.

${ }^{3}$ College of Education and Leadership, Walden University, Minneapolis, Minnesota.
} 
and have done so in a number of ways. Not only do they prepare students to live and work within a technological world, these newer technologies can be used to enhance student engagement and improve learning outcomes. ${ }^{16-19}$ For example, Apple's iTunes University (http://www.apple .com/itunesu/) allows students to download lectures onto an MP3 player to listen to as they walk to class. ${ }^{20}$ Recent campus emergencies have revealed how the "instant" quality of these newer communication strategies is also a key component of safety and security. ${ }^{2}$ Nowadays, at the touch of a button, a detailed voice mail or text message can be sent to all faculty, staff, and students in a matter of seconds, and received on any number of mobile devices. A question arises, however, as to whether everyone gets the message.

\section{Digital inequalities on campus}

As compared to other societal groups, college students tend to be some of the heaviest users of technology. ${ }^{12,14,21}$ Yet educators should be aware that important inequalities in technology use may still exist between subgroups of students, which reflect the broader sociocultural strata in society. ${ }^{4} \mathrm{We}$ conceptualize these inequalities along two dimensions: (a) a digital divide in access to or use of technology, and (b) digital inequalities in how technologies are used. 5,6 Differences in the level of usage have been found in members of ethnic-minority groups, $5,6,22,23$ women, ${ }^{24-26}$ and individuals from lower socioeconomic levels. ${ }^{5,6,23,27,28}$ This important research on access has almost exclusively focused on computers and the Internet, however, and has rarely addressed the communication technologies that are increasingly popular with college students (for an exception, see Hargittai ${ }^{6}$ ). Hence, for this study, we examined three of the key predictors of digital inequality in both ownership and use of communication technologies.

Gender. Although the original gender gap in computer and Internet use appears to have narrowed to the point of nonexistence, ${ }^{5,6,22}$ studies suggest that men and women use these technologies in different ways. ${ }^{21,29,30}$ For example, adolescent girls (aged 15-17) are slightly more likely than boys to use home computers for e-mail, word processing, and completing school assignments as opposed to connecting to the Internet, creating spreadsheets or databases, using graphics and design software, managing household records or finances, or playing games. ${ }^{21}$ Although time spent online is about equal for both genders, more female college students use the Internet for e-mail ${ }^{29,30}$ and to conduct academic research than males. ${ }^{29,31}$ Male college students are also more likely to research purchases, look for news, and play games online. ${ }^{29}$ Related research has suggested that, in general, women are more likely to use the Internet for interpersonal communication, while men are more likely to use it for entertainment and to shop online. ${ }^{21,26,32}$

Ethnicity and income. In many fundamental ways, digital inequalities could be considered to be a result of the larger income divide in society. Although many students own a computer, some students do not. Hence, they must use them in campus labs, which results in a different user experience that may have implications for technology skills. ${ }^{6}$ Furthermore, income and ethnicity are so intricately intertwined in US society that it makes separate discussions of these vari- ables difficult. ${ }^{33,34}$ For example, white and Asian students are more likely to use computers and the Internet than their counterparts, partially because of the disproportionate resources available to them at school and at home, and partially because of cultural and societal influences that encourage their use of technology and discourage use by students of other ethnicities. ${ }^{6,7,23,27,28,35,36}$ Because of their interrelatedness, these two variables are worth considering for studies of college-student use of technology. ${ }^{4}$

\section{A focus on communication technologies}

Most research into aspects of digital inequality has concerned Internet access and computer use but has not addressed newer communication technologies currently being used by students. In this study, we begin to remedy this oversight by examining students' electronic communication patterns related to cell-phone use, text messaging, and IM, and identifying any differences in access and use based on gender, ethnicity, and income. Clarifying those differences should help higher-education researchers, staff, and administrators better understand how students interact with the university and with each other.

Cell phones. University administrators have started to recognize the impact and potential of cell phones as a communication device. ${ }^{1,16}$ The vast majority of students (94\%) report owning one, and many $(42 \%)$ have no landline number. ${ }^{7}$ Not only do cell phones allow one-to-one voice communication, the newer smart mobile devices also provide text messaging, web browsing, calendaring, data storage and retrieval, e-mailing, music listening, and even television viewing-all in a single device. In the next few years, these mobile devices are "likely to have a large impact on teaching, learning, or creative expression within higher education." ${ }^{\prime 37}$ Important to this research, cell-phone service is not particularly cheap and, hence, may correlate with income, especially when data plans are added to or bundled with voice service. Further, as noted above, emerging research suggests that technology that supports increased social interaction tends to be used more frequently by women.

Texting and instant messaging. Both messaging strategies rely on short text messages sent between users in real time, as opposed to the typically longer and asynchronous messages exchanged through e-mail. IM is the equivalent of a text-based conversation or chat between individuals on computers, using various Web sites, applications, or service providers (e.g., Facebook, Myspace, Adium, Yahoo, AOL, MSN, Skype, Google), although voice and video may be used as well. When logged into the service on their computers, students' IM clients have the additional ability to show their buddy lists, which provide information on the availability of their contacts. In contrast, texting relies on the instantaneous communication of a short text message (no more than 160 characters) between cell-phone devices through Short Message Service (SMS) gateways. Although slightly more asynchronous than IM, a text message appears immediately on a digital phone, which a student is more likely to carry than their personal computer. In both cases, students must purposively share their contact information with others in order for these messaging processes to work. 
An exploration of these communication strategies is important to understanding the current user climate on campus, as $75 \%$ of students have reported using IM, and they typically spend as many as 80 minutes a day in these conversations. ${ }^{7}$ When students do use e-mail, it is mainly for "business" and class-related purposes. ${ }^{9}$ Only $5 \%$ of students reported using chat or IM to communicate with professors, who tend to rely more heavily on e-mail for correspondence. ${ }^{12}$ College students also use text messaging frequently, with $57 \%$ reporting that they text messaged at least once a day, and $7.1 \%$ reporting that they text messaged more than seven times a day. ${ }^{38}$

\section{Research questions and hypotheses}

Administrators, staff, and faculty must be able to contact and communicate with students. Typed, paper letters are no longer as tenable on college campuses, so these university agents try to connect with students via e-mail. Unfortunately, because of issues that include the increasing amounts of unsolicited e-mails and the perceived slowness, students have even begun to eschew e-mail as well. As a result, university agents are turning to more immediate forms of electronic communication, such as text messaging and $\mathrm{IM}_{1}^{7,16,39}$ that are also more informal and social in nature. Access and use of these personal forms of technology are far from universal within the student population, and may also be reflective of the larger digital divide in society. For instance, a recent study by the Pew Internet and American Life Project found that African-Americans had less access to the Internet on laptop and desktop computers; however, they used the Internet on mobile devices at higher rates than whites, which may offset access inequities. ${ }^{40}$

This study focuses on how patterns of college students' use of communication technology (specifically cell phones, text messaging, and instant messaging) and their ownership of cell phones can be predicted by gender, ethnicity, and income. As suggested by previous research and emerging trends, we hypothesize that women will use these particular communication technologies more than men. Further, white and AsianAmerican students are hypothesized to use communication technologies more than students of other ethnicities. Finally, we hypothesize that students' household income will be predictive of their use of communication technologies. The same patterns are expected of cell-phone ownership.

\section{Method}

\section{Participants}

Administrators $(n=37)$ who attended a higher-level administrators' roundtable at a national conference were asked if they would be willing for their institutions participate in a study examining technology usage among college students, and four administrators agreed to participate. All students at two universities and then randomly selected samples (because of procedural concerns, such as sending out too many e-mail requests for research participation in one semester) of students at the two other institutions were surveyed $(N=$ 38,345). All four universities were large, four-year, publicresearch institutions. Three of the institutions were primarily nonresidential. Two institutions were located in the southeastern United States, one was in the Midwest, and one was in the southwestern United States. Students were contacted through their on-campus e-mail accounts and were sent a link to a survey hosted on SurveyMonkey.com, a commercial survey-hosting Web site. Two additional reminders were sent, each a week apart with no incentives given for participation. There were 4,491 responses, giving an overall response rate of $11.7 \%$ (missing data discussed below).

\section{Survey development}

A multi-step process was used to create the survey of student technology use. Qualitative data from three years of student interviews and focus groups collected by the principal investigator were reviewed and compared to the Pew Internet and American Life Project surveys, ${ }^{12,14,15,21,41-43}$ as well as Mastrodicasa and Kepic's ${ }^{38}$ survey of college-student technology use. Questions were then developed that focused on college-student technology use in the areas of: cell phones, Facebook, MySpace, blogs, and IM. After a draft was developed, two groups of 15 college students were asked to review the survey and provide feedback. This feedback was used to refine the survey further, which was then pilot tested with another group of 25 students. The survey was revised once more and was sent to higher-education faculty and staff for input. Lastly, feedback from faculty and staff was integrated into the final version of the survey, which contained 56 questions.

We analyzed seven questions from the survey. We asked students to report their gender, whether they owned a cell phone, whether they owned a computer, and their ethnic background (Asian-American, Caucasian, African-American, Native American, Latino-American, or Other). We collapsed the Native American and Other categories due to an extremely low percentage of Native Americans in the sample. The question about parental income included choices for: less than $\$ 9,999 ; \quad \$ 10,000-\$ 14,999 ; \quad \$ 15,000-\$ 24,999 ; \$ 25,000$ 34,$999 ; \$ 35,000-\$ 49,999 ; \$ 50,000-\$ 74,999 ; \quad \$ 75,000-\$ 99,999$; $\$ 100,000-\$ 149,999 ; \$ 150,000-\$ 199,999$, and $\$ 200,000$ and above. Students were asked how many hours and minutes per week they used their cell phones and IM (which were converted to minutes per week) and how many text messages they sent each week.

\section{Procedure}

Students were contacted through their on-campus e-mail accounts during the fall 2006 and spring 2007 semesters. Students were sent a link to a survey hosted on SurveyMonkey.com, a commercial survey-hosting Web site. Students logged onto the survey site and entered their answers. The data were downloaded in raw form, screened for anomalies, and analyzed using PASW 17.0 statistical software (SPSS, Inc., Chicago, IL). The categorical data were recoded to reflect a numerical scale (e.g., those who responded that they were Asian-American were coded as " 1 ") for use in the regression analyses.

\section{Missing data}

Missing cases were noted for variables addressing whether students owned a computer, how much they communicated via cell phones and IM, and many of the demographics. Only two respondents did not indicate whether or not they owned a cell phone. We conducted a full missing-data analysis and 
determined that all of the cases that were missing data regarding owning a computer (714) were also missing information on the demographic variables. After reviewing the raw data and the survey itself, we determined that respondent attrition was the cause. The measures in question were at the end of the survey, which those respondents did not complete. Because all of the same cases were missing data on the same variables, we decided to drop those cases, effectively running the regressions with listwise deletion. The full missing-data analysis is available from the authors upon request.

\section{Data analyses}

Descriptive and inferential statistics illustrate the characteristics of students' technology use, as well as what factors influence such use. We conducted hierarchical (blocked) ordinary least squares (OLS) linear regression analyses to determine which factors influence technology use. For these analyses, we used blocked regression to assess the contribution of each set of variables to the model. The blocks, in order, were: income, ethnicity, and gender. Because OLS regression is a poor choice when the outcome variable is dichotomous, ${ }^{44-46}$ we used logistic regression to analyze technology ownership. Because the measures of kurtosis for the cellphone use, text messaging, and instant messaging variables were unacceptable, we conducted a natural log transformation of those variables to use in the OLS regression analyses.

\section{Results}

\section{Descriptive statistics}

The mean age of the respondents was 23.06 years with a standard deviation of 6.818 and a range of 17-63. Women comprised $62 \%$ of respondents, and men $38 \%$. The sample was disproportionately white $(77 \%)$, but also included AfricanAmericans (7\%), Latino-Americans (7\%), Asian-Americans $(3 \%)$, and $7 \%$ of respondents reporting their ethnicity as other. When discussing income, $3.5 \%$ of students said they were in the less than $\$ 9,999$ per year income bracket, $2.5 \%$ in the
$\$ 10,000-14,999$ bracket, $5 \%$ in the $\$ 15,000-24,999$ bracket, $8.3 \%$ in the $\$ 25,000-34,999$ bracket, $12.9 \%$ in the $\$ 35,000-49,999$ bracket, $22.8 \%$ in the $\$ 50,000-74,999$ bracket, $17.1 \%$ in the $\$ 75,000-99,999$ bracket, $16.1 \%$ in the $\$ 100,000-149,999$ bracket, $6.5 \%$ in the $\$ 150,000-199,999$ bracket, and $5.4 \%$ in the $>\$ 200,000$ bracket. Lastly, $97 \%$ reported that they owned a cell phone and $97 \%$ reported that they owned a computer. The demographics of our sample were representative of the demographics of the students at the institutions surveyed.

\section{Cell-phone ownership and usage}

The results of the logistic regression analysis indicated differences among gender, ethnicity, and income in the ownership of cellular telephones $\left(\operatorname{LR} \chi_{(14)}^{2}=61.577, p<0.001\right)$, with a goodness-of-fit Nagelkerke $R^{2}$ of 0.09 (Table 1). AfricanAmericans were less likely to own a cell phone than white students, and male students had a lower chance of owning a cell phone than women. Students from the lowest parental income level $(<\$ 9,999$ a year) were less likely to own a cell phone than those from the $\$ 50,000-\$ 74,999$ bracket (the median bracket). In addition, students from the $\$ 100,000$ $\$ 149,999$ bracket were more likely to own a cell phone. The reference categories were female, white students, and students from the $\$ 50,000-\$ 74,999$ bracket.

The coefficients and odds ratios listed in Table 1 indicate the effect of a change in each estimator on the probability (or odds) of a student owning a cell phone. The unstandardized coefficients listed in the table may be interpreted similarly to those produced by linear-regression methods, but, because of the nature of the logistic-regression equation, the results are in terms of log odds. For example, being a member of the lowest parental income bracket reduces by 1.09 units the log odds of a student owning a cell phone. Such descriptions are difficult to interpret. Therefore, it can be easier to understand logistic-regression results that are reported in terms of odds ratios.

Odds ratios are the comparison of the probability of one event occurring versus another. One may use odds ratios to report effect size in a similar manner to the regression coef-

Table 1. Results of Logistic Regression Exploring the Relationship of Students' Gender, Ethnicity, and Parental Income to Their Odds of Owning a Cell Phone $(N=3008)$

\begin{tabular}{|c|c|c|c|c|c|}
\hline Independent variables & $\beta$ & $S E$ & $z$ & OR & Inverse $O R$ \\
\hline Male & -0.814 & 0.220 & $13.708^{* * *}$ & 0.443 & 2.257 \\
\hline African-American & -0.744 & 0.314 & $5.629^{*}$ & 0.475 & 2.105 \\
\hline Latino-American & 0.215 & 0.441 & 0.237 & 1.239 & \\
\hline Asian-American & 0.157 & 0.609 & 0.067 & 1.170 & \\
\hline Other ethnicity & 0.264 & 0.447 & 0.348 & 1.302 & \\
\hline$<\$ 9,999$ & -1.086 & 0.410 & $7.005^{* *}$ & 0.338 & 2.959 \\
\hline$\$ 10,000-\$ 14,999$ & -0.647 & 0.521 & 1.546 & 0.524 & \\
\hline$\$ 15,000-\$ 24,999$ & -0.611 & 0.413 & 2.193 & 0.543 & \\
\hline$\$ 25,000-\$ 34,999$ & 0.038 & 0.422 & 0.008 & 1.039 & \\
\hline$\$ 35,000-\$ 49,999$ & -0.472 & 0.319 & 2.200 & 0.624 & \\
\hline$\$ 75,000-\$ 99,999$ & 0.751 & 0.418 & 3.222 & 2.118 & \\
\hline$\$ 100,000-\$ 149,999$ & 1.211 & 0.500 & $5.859^{*}$ & 3.357 & \\
\hline$\$ 150,000-\$ 199,999$ & 1.920 & 1.027 & 3.495 & 6.818 & \\
\hline$>\$ 200,000$ & 1.062 & 0.746 & 2.031 & 2.893 & \\
\hline Constant & 3.795 & 0.254 & $222.756^{* * *}$ & 44.472 & \\
\hline Likelihood ratio $\chi^{2}$ & $61.577^{* * *}$ & & & & \\
\hline Nagelkerke $R^{2}=0.09$ & & & & & \\
\hline
\end{tabular}

${ }^{*} p<0.05 ;{ }^{* *} p<0.01 ;{ }^{* * *} p<0.001$. 
ficients. In fact, the coefficients $(\beta)$ are the natural logs of their respective odds ratios. Odds ratios (OR) can be produced from coefficients by performing the following transformation: $\mathrm{OR}=\mathrm{e}^{\beta}$. Using the previous predictor as an example, one may report that, "The odds of owning a cell phone for students whose parents have a yearly income less than $\$ 10,000$ is $34 \%$ that of students whose parents are in the median income bracket." In the same manner, one can report that the odds of owning a cell phone for students who are male or AfricanAmerican are $44 \%$ and $48 \%$ that of females or white students respectively.

Odds ratios are not linearly additive. In order to compare the relative effect of odds ratios greater than one to those less than one, a researcher can take the inverse of one set of odds ratios. ${ }^{47}$ For example, the negative effects of gender and low parental income listed above can be compared to the positive effects of high parental income by taking the inverse of the OR for predictors with negative coefficients (Table 1). So, the negative effect on the odds of owning a cell phone of being a male (2.257) is less than that of having parents in the lowest income bracket (2.959), while both are lower than the positive effects of having parents in the $\$ 100,000-\$ 149,999$ income bracket (3.357). Inverse odds ratios were only calculated for significant estimators.

Cell-phone usage was examined via hierarchical blocked linear regression. A similar pattern of results were found in these analyses, $F(14,2870)=16.200, p<0.001$, with the full model accounting for $7 \%$ of the variability. Higher cellphone usage was associated with being female, AfricanAmerican, Latino, or from the $\$ 150,000-\$ 199,999$ or $\$ 200,000+$ household-income groups (Table 2). The reference categories were female, white students, and students from the $\$ 50,000$ $\$ 74,999$ bracket. Using hierarchical linear regression allows the researcher to choose the number and order of predictors inserted into the model, "blocking" or grouping them based upon a theoretical construct. The blocked regression analysis indicated that all three sets of variables predicted cell-phone use, with two-thirds of the variability predicted by gender. The results indicate that ethnicity accounted for more of the variability in cell-phone use than income.

\section{Communication strategies}

We used two blocked hierarchical linear regressions to determine whether gender, ethnicity, and/or household income were predictive of how much time per week students spent actively chatting on IM, and how many text messages students sent per week. In contrast to our expectations, the first model did not show any predictive relationship, $F(14$, $1952)=0.864, p=0.599$, of time spent chatting on IM to the three primary variables in this study.

Text messaging. The second full linear regression model did explain students' use of text messaging, $F(14,2049)=5.197$, $p<0.001$ accounting for $2.8 \%$ of the variance in the measure. Table 3 shows the summary of the regression analysis for number of text messages sent per week. The $\$ 100,000$ $\$ 149,999, \$ 150,000-199,000$, and $\$ 200,000$ + household-income levels were significant predictors of texting. In addition, being a female student was positively associated with the number of text messages sent per week, as was being African-American. The reference categories were female, white students, and students from the $\$ 50,000-\$ 74,999$ bracket. The hierarchical regression results indicated that gender and the combination of income and race contributed equally to predicting students' text messaging.

\section{Discussion}

Arguably, cell phones have become pocket-size "mobile computers" that provide similar technological access and service. Students can lead a digital lifestyle almost 24-7 if they so choose. These advantages are not lost on campus officials, who now rely on this immediacy and ubiquity when communicating with constituents. Decades of research on digital inequality urges a measured approach, however, as important differences may still persist. ${ }^{5,6,22-30,32,48}$ In this study, we examined a few of these newer communication technologies and practices available to students, which have direct relevance to campus strategies for disseminating information.

Before discussing the results, one overall aspect of this study is worth noting. Although the logistic regression analysis and

Table 2. Hierarchical Regression Model Exploring How Parental Income, Ethnicity, or Gender Predict Minutes per Week Students Talk on Their Cell Phone $(N=2899)$

\begin{tabular}{lccc}
\hline & $\begin{array}{c}\text { Block 1: Parental income } \\
\text { Independent variables }\end{array}$ & $\begin{array}{c}\text { Block 2: Ethnicity } \\
\beta\end{array}$ & $\begin{array}{c}\text { Block 3: Gender } \\
\beta\end{array}$ \\
\hline$<\$ 9,999$ & 0.004 & -0.011 & -0.011 \\
$\$ 10,000-\$ 14,999$ & 0.003 & -0.005 & -0.001 \\
$\$ 15,000-\$ 24,999$ & 0.020 & 0.008 & 0.011 \\
$\$ 25,000-\$ 34,999$ & 0.039 & 0.027 & 0.031 \\
$\$ 35,000-\$ 49,999$ & 0.038 & 0.029 & 0.029 \\
$\$ 75,000-\$ 99,999$ & -0.001 & 0.003 & 0.008 \\
$\$ 100,000-\$ 149,999$ & 0.015 & 0.019 & 0.034 \\
$\$ 150,000-\$ 199,999$ & 0.024 & 0.030 & $0.041^{*}$ \\
$>\$ 200,000$ & $0.059^{* * *}$ & $0.064^{* * *}$ & $0.080^{* * *}$ \\
African-American & & $0.144^{* * *}$ & $0.129^{* * *}$ \\
Latino-American & & $0.055^{* *}$ & $0.062^{* * *}$ \\
Asian-American & & 0.008 & 0.014 \\
Other ethnicity & & -0.005 & 0.002 \\
Male & & & $-0.218^{*}$ \\
Adjusted $R^{2}$ & 0.002 & $0.022^{* * *}$ & $0.069^{* * *}$ \\
\hline
\end{tabular}

$\beta=$ Beta, the standardized regression coefficient. ${ }^{*} p<0.05 ;{ }^{* *} p<0.01 ;{ }^{* * *} p<0.001$. 
Table 3. Hierarchical Regression Model Exploring How Parental Incoe, Ethnicity, or Gender Predict How Many Text Messages Students Send per Week $(N=2882)$

\begin{tabular}{lccr}
\hline & $\begin{array}{c}\text { Block } 1: \text { Parental income } \\
\beta\end{array}$ & $\begin{array}{c}\text { Block 2: Ethnicity } \\
\beta\end{array}$ & $\begin{array}{c}\text { Block 3: Gender } \\
\beta\end{array}$ \\
\hline$<\$ 9,999$ & -0.026 & -0.029 & -0.029 \\
$\$ 10,000-\$ 14,999$ & 0.037 & 0.035 & 0.035 \\
$\$ 15,000-\$ 24,999$ & 0.040 & 0.035 & 0.035 \\
$\$ 25,000-\$ 34,999$ & -0.009 & -0.014 & -0.013 \\
$\$ 35,000-\$ 49,999$ & $0.050^{*}$ & 0.048 & 0.046 \\
$\$ 75,000-\$ 99,999$ & 0.023 & 0.023 & 0.027 \\
$\$ 100,000-\$ 149,999$ & $0.063^{*}$ & $0.064^{*}$ & $0.073^{* *}$ \\
$\$ 150,000-\$ 199,999$ & 0.047 & 0.048 & $0.053^{*}$ \\
$>\$ 200,000$ & $0.108^{* * *}$ & $0.111^{* * *}$ & $0.120^{* * *}$ \\
African-American & & $0.060^{* *}$ & $0.055^{*}$ \\
Latino-American & & 0.018 & 0.022 \\
Asian-American & & -0.039 & -0.040 \\
Other ethnicity & & -0.018 & -0.015 \\
Male & & & $-0.115^{* * *}$ \\
Adjusted $R^{2}$ & $0.011^{* * *}$ & $0.015^{* * *}$ & $0.028^{* * *}$ \\
\hline
\end{tabular}

$\beta=$ beta, the standardized regression coefficient. ${ }^{*} p<0.05 ;{ }^{* *} p<0.01 ;{ }^{* * *} p<0.001$.

two of the three linear regression analyses produced statistically significant results, only a small proportion of the variance was explained; certainly, there was little variance that needed to be explained. As was seen in the descriptive data, most students $(97 \%)$ reported owning a cell phone, which bodes well for future reliance on them. Therefore, it is understandable that only $2.8 \%$ (in the text-messaging model) and $7 \%$ (in the talking-on-the-cell-phone model) of the variances were predicted. However, the large sample size did allow us to detect subtle differences in this group of students, which may have some implications to higher-educational practice. And, unlike computer labs for students who do not own a computer, universities may not feel obligated to provide mobile phones to students who are unable to obtain one.

Consistent with previous research findings on digital inequality and our own expectations, differences were found in cell-phone ownership and use by gender, by individuals from lower income backgrounds, and by minority students. Female students and white students were more than twice as likely as men and African-American students respectively to own a cell phone. Expectedly, given the costs of the phones and plans, the odds that a student from the lowest income bracket (household income $<\$ 9,999$ per year) owned a cell phone were one third that of a student from the median income bracket, while students from the $\$ 100,000-149,000$ income bracket were more than three times as likely to own one than those from the median bracket.

We also found differences in how technology was used by members of different ethnic groups, by gender, and by students from different income brackets. Being female, AfricanAmerican, or from families earning $\$ 100,000$ per year or more each were positive predictors of the number of text messages sent per week. A similar pattern was found for the regression model predicting the amount of time that students spoke on their cell phones. Being female, African-American or Latino, or from the $\$ 150,000-199,999$ or the over $\$ 200,000$ brackets were all positive predictors of the amount of time spent talking on the cell phone each week. Being from the highest income brackets was positively predictive of both talking on the cell phone and texting. No effect was observed for AsianAmerican students, as we had expected, based on previous research.

Interestingly, although the communication process of IM is quite similar to text messaging, no significant results were found. Possibly, gender, ethnicity, and income do not play as much of a role in the use of IM technology because of its direct tie to computer use and access. Computers are now an accepted and required part of the educational process, and almost all college students own or have access to them in computer labs, residence-hall common areas, or the library. ${ }^{7}$ Although they are becoming more common, personal technologies, like cell phones, are not as integral to student academic success, and generally not provided or subsidized by institutions. Therefore, their ownership and use is more likely to be affected because of digital inequities.

\section{Conclusion}

In spite of the fact that the gap in differences by gender for ownership and use of computers and the Internet appears to have narrowed noticeably, we found the influence of this divide in both the ownership and use of communication technology. 5 ,6 Women in this study reported owning and using communication technology more than men; findings that are congruent with research on technology use. ${ }^{24-26,29,30,32,49,50}$ Furthermore, women spent more time talking on their cell phones and sending text messages than men. Although this study appears to be one of the first to examine gender differences in cell-phone use by college students, these results can be understood within the broader context of gender differences in technology use-women, who are generally more social online, tend to be more social using other aspects of technology, such as cell phones. Hence, one could conclude that a campus-wide text-message alert might be received and read by more female students.

Like other research on digital inequalities, we also found differences in technology ownership and use along ethnic demographics, which not only echo previous findings that 
student ethnicity may be associated with usage levels, but also with how students use technology. ${ }^{35,45}$ Even though AfricanAmerican students were less likely to own a cell phone than students from other ethnic groups, there was a positive relationship between being African-American and the number of text messages sent and the amount of time spent talking on cell phones. In other words, although fewer African-American students in this sample owned cell phones, the ones who did actually used them more for texting and talking than students from other ethnicities, including white students. This is congruent with Horrigan's ${ }^{40}$ findings that a higher percentage of African-Americans send text messages than whites. In addition to the increased cell-phone use by African-American students, Latino students spoke on their cell phones more than students from other ethnicities (with the exception of African-American students).

This significant effect of ethnicity on cell-phone communication may be attributed to a number of reasons. The most salient possibility is that African-American and Latino students are using cell phones as convenient tools (congruent with their digital lifestyles) to obtain support from their social network of family and friends. As suggested by Hargittai, ${ }^{6}$ social surroundings influence the use of communication technologies. African-American and Latino students' experiences on campuses that are primarily white (as were the campuses in our sample) continue to be characterized by a sense of being marginalized. ${ }^{51}$ Using cell phones to connect with family and friends allows these students to enlarge their support network to friends at other institutions of higher education, and to communicate more easily with family members about questions they may have about developmental (such as the implications of being a minority student on campus) and practical (such as strategies for "cutting through red tape") college issues.

Income was also an expected predictor of differences in ownership and use. When addressing the needs of college students from diverse social strata, higher-education administrators may look for ways to "level the playing field." However, a review of the college success literature available on ERIC and PsycINFO shows that the focus on areas of academic deficiencies for college students from underrepresented groups rarely addresses the role of technological skills in assuring their success. Therefore, it is especially important to create policies and practices that will benefit students who may not even be "on the same field" as their peers, when considering access to technology. For instance, universities could subsidize the purchase of cell phones for students who cannot afford them, through partnership programs with service providers.

More research is certainly needed to elucidate and elaborate on these findings, as little is known about how students from diverse backgrounds respond within the different contexts in which these technologies are being deployed. For example, a text message from a BFF ("best friend forever") may engender a different response from a student than a campus-wide emergency alert issued by the president. More broadly, educators, who once struggled to get students to turn off their cell phones during instructional time, are changing tactics and utilizing these technologies in the learning process (e.g., using cell phones as classroom "clickers").

Based on these results, digital inequality and the digital divide continue to be relevant guiding metaphors for de- signing interventions in the days ahead. Even though many of today's students have great familiarity with technology and strong technology skills, some students still struggle. Their characteristics are somewhat predictable, and generally consistent with the bulk of research on access and attainment in higher education. Assuring effective campus communication is only one part of a larger educational process, however. Students also need to develop the skills necessary to be successful participants in a global economy that is driven by and through the use of technology. ${ }^{7}$ Implementing programs to make sure that all students have access and developing a range of communication venues are two strategies suggested by these findings.

\section{Disclosure Statement}

No competing financial interests exist.

\section{References}

1. Gale D. (2008) Best practices in emergency communications. Campus Technology. http://campustechnology.com/articles/ 2008/05/best-practices-in-emergency-communications.aspx (accessed Oct. 20, 2009).

2. Mastrodicasa JM. (2008) Technology use in campus crisis. In Junco R, Timm DM, eds. Using emerging technologies to enhance student engagement. New directions for student services issue \#124. San Francisco: Jossey-Bass, pp. 37-53.

3. Zdziarski EL, Dunkel NW, Rollo JM. (2007) Campus crisis management: A comprehensive guide to planning, prevention, response, and recovery. San Francisco: Jossey-Bass.

4. Salter DW. Campuses at the digital divide. About Campus 2001; 5:24-6.

5. DiMaggio P, Hargittai E, Celeste C, et al. (2004) Digital inequality: From unequal access to differentiated use. In Neckerman K, ed. Social inequality. New York: Russell Sage Foundation, pp. 355-400.

6. Hargittai E. (2008) The digital reproduction of inequality. In Grusky D, ed. Social stratification. Boulder, CO: Westview Press, pp. 936-44.

7. Junco R, Mastrodicasa J. (2007) Connecting to the Net generation: What higher education professionals need to know about today's students. Washington, DC: NASPA.

8. Malaney GD. Student use of the Internet. Journal of Educational Technology Systems 2004-2005; 33:53-66.

9. Salaway G, Caruso JB, Nelson MR. (2007) The ECAR study of undergraduate students and information technology. Washington, DC: Educause. http://net.educause.edu/ir/ library/pdf/ers0706/rs/ERS0706w.pdf (accessed Oct. 20, 2009).

10. Tucker C, Brick JM, Meekins B. Household telephone service and usage patterns in 2004: Implication for telephone samples. Public Opinion Quarterly 2007; 71:3-22.

11. Anderson P. (2005) Mobile and PDA technologies: Looking around the corner. JISC Technology and Standards Watch. Horizon scanning reports. http://www.jisc.ac.uk/whatwedo/ services/techwatch/reports/horizonscanning/hs0504.aspx (accessed Oct. 20, 2009).

12. Jones S, Madden M. (2002) The Internet goes to college: How students are living in the future with today's technology. Washington, DC: Pew Internet and American Life Project. http://www.pewinternet.org/ /media//Files/Reports/2002/ PIP_College_Report.pdf.pdf (accessed Oct. 20, 2009).

13. Rainie L, Tancer B. (2007) Wikipedia users. Data memo posted to Pew Internet and American Life Project Web site. 
http://www.pewinternet.org/ /media//Files/Reports/2007/ PIP_Wikipedia07.pdf.pdf (accessed Oct. 20, 2009).

14. Jones S, Fox S. (2009) Generations online in 2009. Washington, DC: Pew Internet and American Life Project. http:// www.pewinternet.org/ /media//Files/Reports/2009/PIP Generations_2009.pdf (accessed Oct. 20, 2009).

15. Rainie L, Horrigan J. (2005) Internet: The mainstreaming of online life. Washington, DC: Pew Internet and American Life Project. http://www.pewinternet.org/ /media//Files/ Reports/2005/Internet_Status_2005.pdf.pdf (accessed Oct. 20, 2009).

16. Junco R, Timm D. (2008) Using emerging technologies to enhance student engagement. New directions for student services issue \#124. San Francisco: Jossey-Bass.

17. Astin A. Student involvement: A developmental theory for higher education. Journal of College Student Development 1999; 40:518-29.

18. Hu S, Kuh GD. Computing experience and good practices in undergraduate education: Does the degree of campus "wiredness" matter? Education Policy Analysis Archives 2001; 9(49). http://epaa.asu.edu/epaa/v9n49.html (accessed Oct. 20, 2009).

19. Nelson Laird TF, Kuh GD. Student experiences with information technology and their relationship to other aspects of student engagement. Research in Higher Education 2005; 46:211-33.

20. Reidel C. (2008) iTunes U-Educators do "cool stuff" with technology. Campus Technology. http://campustechnology .com/Articles/2008/01/iTunes-UEducators-Do-Cool-Stuffwith-Technology.aspx (accessed Oct. 20, 2009).

21. Lenhart A, Madden M. (2005) Teen content creators and consumers. Washington, DC: Pew Internet and American Life Project. http://www.pewinternet.org/ /media//Files/ Reports/2005/PIP_Teens_Content_Creation.pdf.pdf (accessed Oct. 20, 2009).

22. Feller B. (2006) Digital divide still separates students. http:// www.msnbc.msn.com/id/14685703/ (accessed Oct. 20, 2009).

23. Kaiser Family Foundation. (2004) The Digital Divide Survey Snapshot. Menlo Park, CA: Kaiser Family Foundation. http://www.kff.org/entmedia/loader.cfm?url=/commonspot/ security/getfile.cfm\&PageID=46366 (accessed Oct. 20, 2009).

24. Cooper J, Weaver KD. (2003) Gender and computers: Understanding the digital divide. Mahwah, NJ: Lawrence Erlbaum Associates.

25. Jackson LA, Ervin KS, Gardner PD, et al. Gender and the Internet: Women communicating and men searching. Sex Roles 2001; 44:363-79.

26. Joiner R, Gavin J, Duffield J, et al. Gender, Internet identification, and Internet anxiety: Correlates of Internet use. CyberPsychology \& Behavior 2005; 8:371-8.

27. Sax LJ, Ceja M, Teranishi RT. Technological preparedness among entering freshmen: The role of race, class, and gender. Journal of Educational Computing Research 2001; 24:363-83.

28. United States Department of Commerce National Telecommunications and Information Administration (NTIA). (2000) Falling through the Net: Toward digital inclusion: A report on Americans' access to technology tools. Washington, DC: US Dept. of Commerce, Economic and Statistics Administration. http://search.ntia.doc.gov/pdf/fttn00.pdf (accessed Oct. 20, 2009).

29. Odell PM, Korgen $K$, Schumache $P$, et al. Internet use among female and male college students. CyberPsychology \& Behavior 2000; 3:855-62.
30. Sherman R, End C, Kraan E, et al. The Internet gender gap among college students: Forgotten but not gone? CyberPsychology \& Behavior 2000; 3:885-94.

31. Selwyn, N. (2008) An investigation in undergraduates' academic use of the Internet. Active Learning in Higher Education 2008; 9:11-22.

32. Morgan C, Cotten SR. The relationship between Internet activities and depressive symptoms in a sample of college freshmen. CyberPsychology \& Behavior 2003; 6:133-42.

33. Krueger A, Rothstein J, Turner S. (2006) Race, income, and college in 25 years: Evaluating Justice O'Connor's conjecture. Research and occasional paper series: CSHE 19.06. Center for Studies in Higher Education: University of California, Berkeley. http://cshe.berkeley.edu/publications/docs/ROP .Krueger.19.06.pdf (accessed Oct. 20, 2009).

34. Wright EO. Race, class, and income inequality. The American Journal of Sociology 1978; 83:1368-97.

35. Junco R. (2005) Technology and today's first-year students. In Upcraft ML, Gardner JN, Barefoot BO, et al., eds. Meeting challenges and building support: Creating a climate for first-year student success. San Francisco: Jossey-Bass, pp. 221-38.

36. Oblinger DG, Oblinger JL. (2005) Educating the Net generation. Washington, DC: Educause. http://net.educause.edu/ ir/library/pdf/pub7101.pdf (accessed Dec. 14, 2009).

37. New Media Consortium. (2007) The Horizon Report. http:// www.nmc.org/pdf/2007_Horizon_Report.pdf (accessed Dec. 14, 2009).

38. Mastrodicasa JM, Kepic G. (2005) Parents gone wild. Paper presented at meeting of National Academic Advising Association, Las Vegas, NV.

39. Carnevale D. E-mail is for old people. The Chronicle of Higher Education 2006; 53:A27.

40. Horrigan JB. (2009) Wireless Internet use. Washington, DC: Pew Internet and American Life Project. http://www .pewinternet.org/ /media//Files/Reports/2009/WirelessInternet-Use.pdf (accessed Oct. 8, 2009).

41. Fallows D. (2005) How women and men use the Internet. Washington, DC: Pew Internet and American Life Project. http://www.pewinternet.org/ /media//Files/Reports/2005/ PIP_Women_and_Men_online.pdf (accessed Oct. 20, 2009).

42. Horrigan JB. (2006) Home broadband adoption. Washington, DC: Pew Internet and American Life Project. http://www .pewinternet.org/ /media//Files/Reports/2006/PIP_Broad band_trends2006.pdf (accessed Oct. 20, 2009).

43. Lenhart A, Madden M, Hitlin P. (2005) Teens and technology: Youth are leading the transition to a fully wired and mobile nation. Washington, DC: Pew Internet and American Life Project. http://www.pewinternet.org/ /media//Files/ Reports/2005/ PIP_Teens_Tech_July2005web.pdf (accessed Oct. 20, 2009).

44. Cabrera AF. (1994) Logistic regression analysis in higher education: An applied perspective. In Smart JC, ed. Higher education: Handbook of theory and research. New York: Agathon Press, pp. 225-56.

45. Long JS. (1997) Regression models for categorical and limited dependent variables. Thousand Oaks, CA: Sage.

46. Long JS, Freese J. (2006) Regression models for categorical dependent variables using Stata. 2nd ed. College Station, TX: Stata Press.

47. DesJardins SL. A comment on interpreting odds-ratios when logistic regression coefficients are negative, AIR Professional File: The Association for Institutional Research 2001. http:// airweb3.org/airpubs/81.pdf (accessed Oct. 20, 2009). 
48. United States Department of Commerce National Telecommunications and Information Administration (NTIA). (2004) A nation online: Entering the broadband age. Washington, DC: US Dept. of Commerce, Economic and Statistics Administration. http://www.ntia.doc.gov/reports/anol/Nation OnlineBroadband04.pdf (accessed Oct. 20, 2009).

49. Shuell TJ, Farber SL. Students' perceptions of technology use in college courses. Journal of Educational Computing Research 2001; 24:119-38.

50. Cotton SR, Jelenewicz SM. A disappearing digital divide among college students? Peeling away the layers of the digital divide. Social Science Computer Review 2006; 24:497-506.
51. Gurin P, Dey E, Hurtado S, et al. Diversity and higher education: Theory and impact on educational outcomes. Harvard Educational Review 2002; 72:330-66.

Address correspondence to: Dr. Reynol Junco Lock Haven University Lock Haven, PA 17745

E-mail: rey.junco@gmail.com 
